\title{
Evaluation of Charka and Cottage Reeling Units in traditional Silk Producing District of Tamil Nadu, India-An Economic Analysis
}

\author{
D. Elumalai $^{1 *}$, P. Mohanraj ${ }^{1}$, R. Ramamoorthy ${ }^{1}$, C. Mohan ${ }^{2}$ and B. Poovizhiraja ${ }^{3}$ \\ ${ }^{1}$ Department of Sericulture, Forest Collage and Research Institute, \\ Mettupalayam, Coimbatore, Tamil Nadu, India \\ ${ }^{2}$ Department of Agricultural Entomology, Palar agricultural college, \\ Ambur, Vellore, Tamil Nadu, India \\ ${ }^{3}$ Department of Plant Protection, \\ Agricultural Collage and Research Institute, Madurai, Tamil Nadu, India \\ *Corresponding author
}

\section{A B S T R A C T}

\begin{tabular}{|l|}
\hline Key w or d s \\
Cost and return, \\
$\begin{array}{l}\text { Silk reeling, } \\
\text { Charka, Cottage } \\
\text { and Constraints }\end{array}$ \\
\hline Article Info \\
\hline $\begin{array}{l}\text { Accepted: } \\
\text { 05 June } 2020 \\
\text { Available Online: } \\
\text { 10 July } 2020\end{array}$ \\
\hline
\end{tabular}

The study was conducted in the traditional silk producing district of Tamil Nadu. The traditional silk producing district like Dharmapuri and Krishnagiri was selected. Using random sampling techniques identified in the charka and cottage reelers. Totally 60 samples are selected. From the primary data observed that charka reelers per day reeling capacity of $15 \mathrm{~kg} /$ machine. The total expenditure of charka reelers Rs. 6685 as on $15 \mathrm{~kg}$ of cocoon and one $\mathrm{kg}$ of expenditure observed as Rs. 2971. Raw silk reeled per basin per day in charka $2.25 \mathrm{~kg}$ and total returns work out for Rs.7775. The net return realized for Rs.1110, respectively. Next, cottage reelers per day reeling capacity of machine $60 \mathrm{~kg}$ of cocoon. Total production cost of reeling cocoon of Rs. 25704.30. Raw silk reeled per basin five per day in cottage $8.67 \mathrm{~kg}$. The total return calculated for Rs. 29385.50 and net return realized for Rs.3681.TheB.C ratio worked out to be least in charka and high in cottage reeling machine. So as renditta was high charka and low cottage basin was observed in the study. The major problem faced by reelers irrespective of reeling system was problems related to working capital like lack of institutional credit especially short-term credit availability. Labour was next factor which includes shortage of skilled labour especially women labour. The improper weighment of cocoons and nonavailability of quality cocoons regularly were problems at market level. The other problems like reelers were lack of remunerative price for domestic silk, unaware of government policies on imports and import tariffs on silk from China.

\section{Introduction}

Silk is one of the more cost, less quantity natural fibers. In the middle of all the silk cloths, silk is the only natural, insect made and producing fiber which has anice-looking luster, colour, stylish appearance. silk has always been most cherished and sought of all textile fibres, like; cotton wool and silk, silk accounts for 0.38 per cent (Khan, 2010). Hence, silk fiber is considered to be the queen of textiles. Silk industry plays an important role in shaping the rural nation of India by given that employment to maximum than eight millions (Anon, 2016) and streamlining the continuous flow of income to many rural 
and semi-urban masses. the labour requirement was 1.33 man days per $\mathrm{kg}$ of raw silk (Chandra Reddy, 1993). It is a vital agrobased cottage rural industry, which covers the many sericulture activities like mulberry cultivation, silkworm rearing and cocoon production, silk reeling, twisting, weaving and dying etc. quality of the final product, 'silk' has been standard as a natural textile fiber and as one of the high-cost, low-volume commodities to trade between the continents from time immemorial.

Yet nowadays no other cloth matches its luster, durability, lightness, elegance and luxury. Today, sericulture is changed into a seri-business and profit multiplying venture. The quality of fabric with rich designs is produced on grade handloom in India. Improved reeling machines such as cottage basin and multi end basin were installed to get good quality of mulberry silk yarn (Sonwalkar et al., 1987). The study of the management of silk reeling and weaving units would be of immense use as a whole to prescribe appropriate measures for improvement. Hence, an attempt has been made to assess the management of silk industry in Tamil Nadu with the following Objectives include to analysis cost and returns of different traditional types of silk reeling units in Tamil Nadu. And also to estimate constraints faced by the reeling units and give to suggest measures.

\section{Materials and Methods}

This study was carried out in traditional area of Tamil nadu. The traditional area such as Dharmapuri and Krishnagiri district was selected and these areas maximum reelers and twisters are producing raw silk and twisted silk. Total 60 samples were randomly selected from above the two district of Tamil Nadu. The primary data necessary for the study was collected from the randomly selected units on the general socio economic characteristics, cost and returns of silk reeling, twisters and problems faced by silk industry units.

The estimation of cost of production of raw silk under different units of (charka and cottage-basin) gross income and net income from these systems of reeling and twisting. The frequency, percentage and rank were used as statistical measures to analyze the data. The major constraints taken into consideration were related to silk reeling and twisting.

\section{Garrett's ranking technique}

This technique was used to analyse the factors that were influencing the quantity of purchase of cocoons by reelers and the problems faced by reelers in the industry, constraints in reeler, and twisters. The selected sample respondents were asked to rank the factors that were limiting the quantity of raw materials purchase.

Similarly, the problems that were identified were listed and the respondents were asked to assign ranks to them according to their importance. The order of merit thus given by the respondents was converted into per cent position using the following formula:

Per cent position $=100 \times(\mathrm{Rij}-0.5) / \mathrm{Nj}$

Where Rij = rank given for ith factor by $j^{\text {th }}$ individual

$\mathrm{Nj}=$ number of factors ranked by $\mathrm{j}^{\text {th }}$ Individual

The per cent position of each rank thus obtained was transformed into scores by referring to the Garrett table (Woodworth, 1969). Then the scores of each individual for each factor were added together and divided by the total number of respondents for whom the scores were added. These mean scores for all the factors were added. These mean scores 
for all the factors were arranged in descending order and ranks were assigned as per the order. By this method, the most limiting factors and the most important problems were identified

\section{Results and Discussion}

\section{Raw silk production in cottage reeling}

The raw silk production in cottage reeling has been presented in Table.1. The purchased cost of cocoon was Rs.21000 accounted for 81.69 per cent followed by other expenses of packing materials (Rs. 160; 0.62\%), loading and unloading (Rs. 50; 0.19\%), transportation cost (Rs. 120; 0.46\%) and remaining belong to miscellaneous (Rs.100; 0.38\%). the total procurement cost of cocoon in cottage reeling per unit per day was Rs.21430 was represented.

About, processing cost of labour in cottage reeling machine majority of sample respondents found were high wages rate was incurred towards in reeling labour charges (Rs.960; 3.73\%) followed by wastage of cleaning labour charges, cocoon cooking labour charges (Rs.420; 1.63\%) and winding labour charges (Rs.300; 1.16\%).

The minimum expenditure was incurred towards fuel charges (Rs. 450; 1.86\%), firewood and water (Rs.350; 1.36\%), supervisor charges (Rs.300; 1.16\%) and electrical charges (Rs.72; 0.28\%). the total processing cost of cottage reeling per day per unit was Rs.3712 accounted for 14.44 per cent.

Next, marketing cost of raw silk, majority of sample respondents found were in transportation and miscellaneous charges (Rs.350; 1.36\%) followed by packing materials (Rs.100; 0.38\%), transportation cost of raw silk (Rs.92.30; 0.35\%) and remaining belong to loading and unloading charges (Rs.20; 0.07\%). The total marketing cost of raw silk recorded was Rs.562.30 accounted for 2.18per cent.

The total expenditure of cottage reeling per unit per day was Rs.25704.30. The total return in main product was Rs.27310.50 accounted for 92.93 per cent followed by product like the wastage of silk (Rs.1500; $5.10 \%$ ), defective cocoon (Rs.500; 1.70\%) and pupa (Rs.75; 0.25\%). The total return obtained per unit was Rs. 29385.50 with net returns from raw silk of Rs. 5437.50. The net return obtained from cottage reeling machine per unit per day was Rs.3681.20.

\section{Raw silk production in charka reeling}

The raw silk production in charka reelers has been presented in Table 7 . In charka reelers, the purchased cost of cocoon in charka reeler was Rs.5250 accounted for 78.53 per cent followed by minimum costs was incurred towards transportation cost of cocoon (Rs. 30; $0.44 \%$ ), packing material (Rs.80; 1.19\%), loading and unloading (Rs. 20; 0.29) and remaining belong to miscellaneous (Rs.100; $1.49 \%)$. The total cost of procurement of cocoon in charka reeling per unit per day was Rs.5480 was represented.

In charka reeling machine, the maximum share of higher labour charges in the multiend reeling units found were in reeling labour charges (Rs.240; $3.59 \%$ ) followed by wastage of cleaning and winding charges (Rs.240; 3.59\%). The minimum expenditure was incurred towards firewood (Rs. 120; $1.79 \%)$, water (Rs.100; 1.49\%) and electrical charges (Rs.100; $1.49 \%$ ). the total processing cost of multiend reeling per day per unit was Rs.732 accounted for 10.94 per cent. 
Table.1 Cost and returns of raw silk production in cottage reeling units 5 basins/per day

1. Cost

\begin{tabular}{|c|c|c|c|c|c|c|c|}
\hline S.No & Particulars & Unit & $\begin{array}{c}\text { Quantit } \\
\mathbf{y}\end{array}$ & $\begin{array}{l}\text { Price/unit } \\
\text { (Rs.) }\end{array}$ & $\begin{array}{c}\text { Amount } \\
\text { (Rs.) }\end{array}$ & Percentages & $\begin{array}{r}\text { Per kg of } \\
\text { cost }\end{array}$ \\
\hline \multicolumn{8}{|c|}{ I. Procurement of cocoon } \\
\hline 1 & Cocoon purchased & $\mathrm{Kg}$ & 60 & 350 & 21000 & 81.69 & 2422.14 \\
\hline 2 & Packing materials & Nos. & 2 & 80 & 160 & 0.62 & 18.45 \\
\hline 3 & Loading/unloading & & - & - & 50 & 0.19 & 5.67 \\
\hline 4 & $\begin{array}{l}\text { Transportation cost of } \\
\text { cocoon }\end{array}$ & Kg. & 60 & 2 & 120 & 0.46 & 13.84 \\
\hline \multirow[t]{2}{*}{5} & Miscellaneous & - & - & - & 100 & 0.38 & 11.53 \\
\hline & \multicolumn{4}{|c|}{ Total Procurement cost of cocoon (I) } & 21430 & 83.37 & 2471.74 \\
\hline \multicolumn{8}{|c|}{ II. Processing } \\
\hline \multirow[t]{5}{*}{1} & \multicolumn{5}{|l|}{ Labour charges } & & \\
\hline & Reeling labour & Nos. & 4 & 240 & 960 & 3.73 & 110.72 \\
\hline & $\begin{array}{l}\text { Wastage } \\
\text { cleaning }\end{array}$ & Nos. & 2 & 240 & 480 & 1.86 & 55.36 \\
\hline & Winding & Nos. & 1 & 300 & 300 & 1.16 & 34.60 \\
\hline & Cooking & Nos. & 2 & 240 & 480 & 1.86 & 55.36 \\
\hline 2 & Firewood & - & - & - & 350 & 1.36 & 40.36 \\
\hline 3 & Electrical charges & Unit & 9 & 8 & 72 & 0.28 & 8.30 \\
\hline 4 & Water & - & - & - & 350 & 1.36 & 40.36 \\
\hline 5 & Fuel & Lit. & 6 & 70 & 420 & 1.63 & 48.44 \\
\hline \multirow[t]{2}{*}{6} & Supervisor & Nos. & 1 & 300 & 300 & 1.16 & 34.60 \\
\hline & \multicolumn{4}{|c|}{ Total Processing charges (II) } & 3712 & 14.44 & 428.14 \\
\hline \multicolumn{8}{|c|}{ III. Marketing cost of raw silk } \\
\hline 1 & $\begin{array}{l}\text { Transportation cost of } \\
\text { raw silk }\end{array}$ & $\mathrm{Kg}$. & 8.67 & 10.64 & 92.30 & 0.35 & 10.64 \\
\hline 2 & Packing materials & Nos. & 1 & 100 & 100 & 0.38 & 11.53 \\
\hline 3 & Loading/ unloading & - & - & - & 20 & 0.07 & 2.30 \\
\hline \multirow[t]{3}{*}{4} & $\begin{array}{l}\text { Transport charges and } \\
\text { miscellaneous }\end{array}$ & - & - & - & 350 & 1.36 & 40.36 \\
\hline & \multicolumn{4}{|c|}{ Total marketing cost of raw silk (III) } & 562.30 & 2.18 & 64.85 \\
\hline & \multicolumn{4}{|c|}{ Total expenditure (I+II+III) } & 25704.30 & 100.00 & 2964.74 \\
\hline
\end{tabular}


Table.2 Returns

\begin{tabular}{|c|c|c|c|c|c|c|c|}
\hline S.No & Details & Unit & Quantity & $\begin{array}{l}\text { Price/unit } \\
\quad \text { (Rs.) }\end{array}$ & $\begin{array}{l}\text { Amount } \\
\text { (Rs.) }\end{array}$ & Percentage & $\begin{array}{l}\text { Per kg } \\
\text { of cost }\end{array}$ \\
\hline \multicolumn{8}{|c|}{ 1.Main product } \\
\hline & $\begin{array}{l}\text { Quality of raw silk } \\
\text { (18 to } 20 \text { Diner) } \\
\text { (6.92 Renditta) }\end{array}$ & $\mathrm{Kg}$. & 8.67 & 3150 & 27310.50 & 92.93 & 3150 \\
\hline \multicolumn{8}{|c|}{ 2. Byproduct } \\
\hline & Sale of pupa & $\mathrm{Kg}$. & 15 & 5 & 75 & 0.25 & 8.65 \\
\hline & Wastages of silk & $\mathrm{Kg}$. & 2 & 750 & 1500 & 5.10 & 173.01 \\
\hline & Defective cocoon & $\mathrm{Kg}$. & 2 & 250 & 500 & 1.70 & 57.67 \\
\hline & \multicolumn{4}{|c|}{ Total returns } & 29385.50 & 100.00 & 3389.33 \\
\hline
\end{tabular}

Table.3 Cost and returns of cottage reelers

\begin{tabular}{|c|l|c|}
\hline S.No. & Details & Amounts (Rs.) \\
\hline $\mathbf{1}$ & Total expenditure & 25704.30 \\
\hline $\mathbf{2}$ & Total returns & 29385.50 \\
\hline $\mathbf{3}$ & Net returns & 3681.20 \\
\hline
\end{tabular}

Table.4 Raw silk production in charka reeling

1. Cost One machine/per day

\begin{tabular}{|c|c|c|c|c|c|c|c|c|}
\hline S.No & \multicolumn{2}{|r|}{ Particulars } & Unit & Quantity & $\begin{array}{l}\text { Price/unit } \\
\text { (Rs.) }\end{array}$ & $\begin{array}{c}\text { Amount } \\
\text { (Rs.) }\end{array}$ & Percentages & $\begin{array}{c}\text { Per kg of } \\
\text { cost }\end{array}$ \\
\hline \multicolumn{9}{|c|}{ I. Procurement of cocoon } \\
\hline 1 & \multicolumn{2}{|c|}{ Cocoon purchased } & $\mathrm{Kg}$. & 15 & 350 & 5250 & 78.53 & 2333.33 \\
\hline 2 & \multicolumn{2}{|c|}{ Packing materials } & Nos. & 1 & 80 & 80 & 1.19 & 35.55 \\
\hline 3 & \multicolumn{2}{|c|}{ Loading/unloading } & - & - & - & 20 & 0.29 & 8.88 \\
\hline 4 & \multicolumn{2}{|c|}{ Transportation cost of cocoon } & $\mathrm{Kg}$. & 15 & 2 & 30 & 0.44 & 13.33 \\
\hline \multirow[t]{2}{*}{5} & \multicolumn{2}{|c|}{ Miscellaneous } & - & - & - & 100 & 1.49 & 44.44 \\
\hline & \multicolumn{5}{|c|}{ Total Procurement cost of cocoon (I) } & 5480 & 81.97 & 2435.55 \\
\hline \multicolumn{9}{|c|}{ II. Processing } \\
\hline \multirow[t]{3}{*}{1} & \multicolumn{6}{|c|}{ Labour charges } & & \\
\hline & 1.1 & Reeling labour & Nos. & 1 & 240 & 240 & 3.59 & 106.66 \\
\hline & 1.2 & $\begin{array}{l}\text { Winding + Wastage } \\
\text { cleaning Labour }\end{array}$ & Nos. & 1 & 240 & 240 & 32.78 & 106.66 \\
\hline 2 & Firev & ood & - & - & - & 120 & 1.79 & 53.33 \\
\hline 3 & Elect & ical charges & Unit & 4 & 8 & 32 & 0.47 & 14.22 \\
\hline \multirow[t]{2}{*}{4} & Wate & & - & - & - & 100 & 1.49 & 44.44 \\
\hline & \multicolumn{5}{|c|}{ Total Processing charges (II) } & 732 & 10.94 & 325.33 \\
\hline \multicolumn{9}{|c|}{ III. Marketing cost of raw silk } \\
\hline 1 & \multicolumn{2}{|c|}{ Transportation cost of raw silk } & $\mathrm{Kg}$. & 2.25 & 10.20 & 23 & 0.34 & 10.20 \\
\hline 2 & \multicolumn{2}{|c|}{ Packing materials } & Nos. & 1 & 50 & 50 & 0.74 & 22.22 \\
\hline \multirow[t]{3}{*}{4} & \multicolumn{2}{|c|}{ Miscellaneous } & - & & & 400 & 5.98 & 177.77 \\
\hline & \multicolumn{5}{|c|}{ Total marketing cost of raw silk (III) } & 473 & 7.07 & 210.22 \\
\hline & \multicolumn{5}{|c|}{ Total expenditure (I+II+III) } & 6685 & 100.00 & 2971.11 \\
\hline
\end{tabular}


Table.5 Returns

\begin{tabular}{|c|c|c|c|c|c|c|c|}
\hline S.No & Details & Unit & Quantity & $\begin{array}{l}\text { Price/unit } \\
\text { (Rs.) }\end{array}$ & $\begin{array}{l}\text { Amount } \\
\text { (Rs.) }\end{array}$ & Percentages & $\begin{array}{l}\text { Per kg of } \\
\text { cost }\end{array}$ \\
\hline \multicolumn{8}{|c|}{ 1.Main product } \\
\hline & $\begin{array}{l}\text { Quality of raw silk } \\
\text { (18 to } 20 \text { Diner) (6.66 Renditta) }\end{array}$ & $\mathrm{Kg}$. & 2.25 & 3150 & 7087.50 & 90.92 & 3150 \\
\hline \multicolumn{8}{|c|}{ 2. Byproduct } \\
\hline & Sale of pupa & $\mathrm{Kg}$. & 4 & 5 & 20 & 0.25 & 8.88 \\
\hline & Wastages of silk & $\mathrm{Kg}$. & 0.75 & 750 & 562.50 & 7.21 & 250 \\
\hline & Defective cocoon & $\mathrm{Kg}$. & 0.50 & 250 & 125 & 1.60 & 55.55 \\
\hline & \multicolumn{4}{|c|}{ Total returns } & 7795 & 100.00 & 3464.44 \\
\hline
\end{tabular}

Table.6 Cost and returns of charka reelers

\begin{tabular}{|c|l|r|}
\hline S.No & Details & Amounts (Rs.) \\
\hline $\mathbf{1}$ & Total expenditure & 6685.00 \\
\hline $\mathbf{2}$ & Total returns & 7795.00 \\
\hline $\mathbf{3}$ & Net returns & 1110.00 \\
\hline
\end{tabular}

Table.7 Constraints faced by reelers

\begin{tabular}{|c|c|c|c|c|c|}
\hline \multirow[t]{2}{*}{ S.No } & \multirow[t]{2}{*}{ Problmes } & \multicolumn{2}{|c|}{$\begin{array}{l}\text { Charka } \\
\text { Reeling }\end{array}$} & \multicolumn{2}{|c|}{$\begin{array}{l}\text { Cottage } \\
\text { Reeling }\end{array}$} \\
\hline & & Score & Rank & Score & Rank \\
\hline & Procurement problems & & & & \\
\hline 1 & Fluctuation in cocoon prices & 444 & I & 744 & I \\
\hline 2 & Absence of quality cocoons & 411 & II & 560 & II \\
\hline 3 & Poor information of market & 349 & III & 516 & III \\
\hline 4 & Poor market facilities & 306 & IV & 498 & IV \\
\hline 5 & Non- availability of space to store cocoons & 253 & V & 359 & V \\
\hline 6 & Long transportation & 191 & VI & 345 & VI \\
\hline \multirow[t]{2}{*}{7} & Delay in cash payments & 158 & VII & 246 & VII \\
\hline & Processing problems & & & & \\
\hline 1 & Poor quality cocoons & 436 & I & 712 & I \\
\hline 2 & Good water/reeling water & 412 & II & 688 & II \\
\hline 3 & Scarcity of labour & 374 & III & 646 & III \\
\hline 4 & High labour cost & 326 & IV & 533 & IV \\
\hline 5 & High cost of silk reeling machines & 219 & VI & 353 & VI \\
\hline 6 & Non- availability of electricity & 180 & VII & 337 & VII \\
\hline 7 & Non- availability of fuel & 178 & VIII & 243 & VIII \\
\hline \multirow[t]{2}{*}{8} & Lack of technical guidence & 248 & V & 434 & V \\
\hline & Marketing problems & & & & \\
\hline 1 & Fluctuation in silk prices & 456 & I & 736 & I \\
\hline 2 & Non-availability of market information & 376 & III & 633 & III \\
\hline 3 & Inadequate storage facility & 159 & VIII & 340 & VII \\
\hline 4 & Inadequate market facility & 252 & VI & 367 & VI \\
\hline 5 & No demand in market & 167 & VII & 243 & VIII \\
\hline 6 & Import silk & 287 & V & 494 & V \\
\hline 7 & Delay in cash & 293 & IV & 512 & IV \\
\hline 8 & Transportation problems & 404 & II & 676 & II \\
\hline
\end{tabular}


Next, marketing cost of raw silk, majority of sample respondents found were in higher transportation and miscellaneous charges (Rs.400; 5.98\%) followed by transportation cost of raw silk (Rs.23.84; 0.34\%), packing materials (Rs.50; 0.74\%). The total marketing cost of raw silk recorded was Rs.473 accounted for 7.07 per cent. The total cost of multiend reeling per unit per day was Rs.6685. The total gross income in main product was Rs.7087.50 accounted for 90.92 per cent followed by -product like the wastage of silk (Rs.562.50; 7.21\%), defective cocoon (Rs.125; 1.60\%) and pupa (Rs.20; 0.25\%). The total return obtained per unit was Rs. 7827.50 with net returns from raw silk of Rs.1110. The net return obtained from charka reeling per unit per day was Rs.1110.

\section{Constraints faced by reelers}

From the above table.7 observed that major problems faced by reelers such as fluctuation in cocoon prices due every day cocoon price was change so that is reason fluctuation in cocoon prices. Reelers wer not able to get good qulality cocoon. Farmers were not involved in grading, sorting and removal of waste from cocoon as per standards. To produce the quality of raw silk, reelers need good quality and uniform cocoons from farmers. management practices carried during reeling were not done as per the standard norms of different reeling units due to poor quality cocoon that led to inferior raw silk as output.

From the table. 7 processing problems faced by the reelers was poor quality of cocoon ranked I. The rank II were given for lack of good quality reeling water in all reeling units. Bore, lake and well water used by reelers having different types of impurities like high amount of salts that affects soubility of sericin and luster of the raw silk.

From the table.7 revealed that marketing problems faced by reelers showed that fluctuation of silk prices and no standard price fixation system for raw silk. Inadequate storage facility among the reelers which leads to the affect the quality of raw silk because silk fibre is natural material which is easily affected by variations in temperature and humidity. Import of raw silk from foreign countries leads to reduce the cost of Indian silk.

Sericulture is a cottage based on rural industry. The silk reelers are got day by day good income generation and also reelers getting self-employment opportunities. The study concluded that the traditional silk reelers like charka reelers produced silk for low demand and poor quality due to renditta and poor socio economic characters. The cottage reelers are marginally got income generation. Constraints faced by reelers such as fluctuation in cocoon prices, poor quality of cocoon, poor quality of water, shortage labour and fluctuation in silk pricesect.

\section{References}

Anonymous, 2016. Note on the performance of Indian silk industry and functioning of Central Silk Board, CSB Publication, P.20.

Chandrareddy, T and Eswaraprasad, T., 1993, An Economic analysis of processing and marketing costs in the silk yarn production. Indian journal of Agricultural marketing., 7(2):226-229.

Khan, R.I, 2010. Production report of silk fiber in the world.Indian journal of sericulture, 32 (4):1-2.

Sonwalkar, T.N., Lakshipathaiah, B.N., and Nagabushaniah, Y.V., 1987, Different system of reeling and their influence on quality of silk. National workshop on silk industry in India ancient traditional to 21th century, April, CSTRI, Bangalore, pp.83-86. 


\section{How to cite this article:}

Elumalai. D., P. Mohanraj, R. Ramamoorthy, C. Mohan and Poovizhiraja. B. 2020. Evaluation of Charka and Cottage Reeling Units in traditional Silk Producing District of Tamil Nadu, India- An Economic Analysis. Int.J.Curr.Microbiol.App.Sci. 9(07): 499-506.

doi: https://doi.org/10.20546/ijcmas.2020.907.055 